\title{
PRECONDITION ON MICROINSURANCE IN UKRAINE: CONTINGENT VALUATION APPROACH FOR POOR POPULATION BEHAVIOUR REGARDING INSURANCE SERVICES
}

(CASE STUDY)

\author{
Lada Shirinyan \\ National University of Food Technologies, Kyiv, Ukraine \\ Aram Shirinyan \\ National University of Food Technologies, Kyiv, Ukraine
}

\begin{abstract}
The work represents the risk-behavioural aspects of finance and insurance related to low-income people in Ukraine and answers the main question concerning microinsurance: can microinsurance provide value for low-income people? The definition of microinsurance is presented. The study uses the contingent valuation method, as it used a survey to directly ask low-income people how much they would be willing to pay for insurance. The polling was performed in 2011-2013 and covered about 3000 people. It is found that Urban poor were found to prefer to have an annual microinsurance premium of less than 3\% of the Minimal Ukrainian Salary (MUS) and the desired size of annual microinsurance coverage was found to be not less than the 3MUS microinsurance tariff, at a rate $1 \%$ of the desired insurance sum.
\end{abstract}

Keywords: microinsurance, contingent valuation, low-income people, price, insurance coverage

DOI: http://dx.doi.org/10.15549/jeecar.v6i2.378

\section{INTRODUCTION}

The topic of insurance to protect low-income people against various perils is new, not only for Ukraine, but for many other developing countries in the world. Over the last decade, much attention throughout the world has been paid to the concept:

- by international organisations and global platforms, such as the United Nations (United Nations), the Consultative Group to
Assist the Poor, housed at the World Bank (CGAP Working group on Microinsurance, 2008), World Bank (Churchill and Matul, 2012; Churchill, 2006), the International Labour Organisation (International Labour Organisation, 2015), the Microinsurance Network (Microinsurance Network, 2019), Opportunity International (Opportunity International, 
2018), and the Bill and Melinda Gates Foundation (Yao, 2013);

- by commercial organisations such as Munich Re, Allianz (McCord, Ramm, McGuinness, 2006);

- by researchers (Churchill, 2007; Llanto, Geron, Almario, 2007; Holst, 2005; Yao, 2013; et al.).

The main question concerning microinsurance is the following: can microinsurance be a viable business proposition and provide value for lowincome people at the same time? This is a very important question for low-income countries, especially post-Soviet countries, because they lack the knowledge and political resources to introduce a necessary open market system in the most optimal way. A real-life illustration of this phenomenon is the situation in Ukraine. With the collapse of the USSR, the Ukrainian insurance system has been under constant reformation in light of its economic system, and the country finds itself in a very fragile stage. According to the World Bank, between 2011 and 2015, the trend of poverty in Ukraine was rising. In 2015, three-quarters of Ukrainians were living below the poverty line, and about $7 \%$ of the country's population was in extreme poverty (The World Bank Group, 2018). Hence, the value of knowledge concerning microinsurance decisions in Ukraine, with its post-communist transition economics, is very high.

\section{Defining the Problem - meaning of microinsurance}

Our present work is devoted to studying the preconditions of introducing a new insurance service, namely microinsurance, for low-income people in Ukraine. Churchill (2007) defined microinsurance as insurance for low-income people. Dror and Jacquier (1999) referred to microinsurance as a financial scheme at the local level. Microinsurance is based on the same principles as standard insurance and offers a mechanism for protecting low-income clients against major risks, such as accidents, illness, death in the family, or natural disasters. In our paper, we are guided by the definition of Shirinyan and Shirinyan (2012), which is based on Churchill's vision (2007), but with a broadened outlook in the following way: microinsurance is a protection service to defend the valuable interests of juridical and physical persons with low income in exchange for low insurance premiums under the condition of small insurance sums, simplified insurance systems, high rates of insurance compensations, and low or no profits for the microinsurance provider.

We assume that microinsurance is likely to develop on a voluntary basis in Ukraine, with poor clients having to pay a small premium. Hence, finding the amounts that low-income clients would be willing to pay is essential, as is finding the key determinants influencing this choice.

\section{Aim of the study}

We aim to add knowledge on the willingnessto-pay for insurance among low-income Ukrainians and identify the key determinants influencing their choices. The purpose of the study is to investigate the need for microinsurance among low-income people in Ukraine and understand the behaviour of the poor population toward insurance services.

\section{Analysis of publications}

Despite the growing interest in microinsurance, academic attention to this topic is still lacking, and little empirical knowledge about the microinsurance market currently exists. The main publications that have studied microinsurance are related to Asian and African Countries (Dror and Jacquier, 1999; Churchill, 2006; Churchill and Matul, 2012). Biener and Eling (2012) provided a comprehensive analysis of the insurability of risks in microinsurance based on a set of fundamental insurability criteria proposed by Berliner (Berliner, 1982).

Key publications on microinsurance in former Soviet Union countries include only a few articles (Grebenshchikov, 2007; Shirinyan, 2010). Unfortunately, such papers are in local journals and unknown to the wider academic audience. Grebenshchikov's article, for example, only represents an overview with basic definitions and understanding. As far as we know, the problem of introducing 
microinsurance to Ukraine has been started by (Shirinyan, 2010, 2012a; Shirinyan and Shirinyan, 2012) except the recent publication of the Microfinance Centre for Central and Eastern Europe and the New Independent States located in Warsaw (Matul, Durmanova, Tounitsky, 2006). That European center made a survey to distribute among the population of Ukraine at different income levels, which confirmed that about 30\% of people thought insurance was of great social use. On the other hand, according to their results, for $20 \%$ the insurance was too expensive and ineffective for their family budget. This one study, however, is not enough to get a whole picture of the behaviours of the poor population of Ukraine regarding insurance services.

Data from India for poor population found that in most cases willingness-to-pay decreases with household income (Binnendijk, Dror, Gerelle, Koren, 2013). Additionally, a recent study of low-income countries demonstrated that the evaluation of willingness-to-pay is also influenced by socioeconomic parameters. Furthermore, there is overwhelming evidence against the expected utility theory (Ramachandran, 2012). We can not use theories of demand for insurance and the results of other authors in the case of the microinsurance services because they do not yet exist in Ukraine. In order to negotiate this obstacle, we opt for the contingent valuation method, which will be discussed further below.

\section{General situation and time distance}

For a start, let us examine the overall situation related to the Ukrainian insurance market (Table 1). Careful analysis of the situation over the past 15 years indicates some trends: i) an increase in the number of insurers with a growth of total assets by 2008; ii) a rapid decrease in the number of insurers after 2014 (Ukraine's Revolution of Dignity against corruption), along with a decrease and fluctuations of assets; iii) a sharp decrease in insurance premiums after 2013, which were; iv) followed by oscillations and a small increase in 2017-2018. In brief, one can see mainly negative tendencies, which drew criticism and questions for the Ukrainian regulatory authorities. In other words, in the 6 years since our survey, the domain of traditional insurance and microinsurance in Ukraine has not changed.

Table 1. Macroeconomic indicators of the insurance services market in Ukraine

\begin{tabular}{|c|c|c|c|c|c|}
\hline Year & $\begin{array}{c}\text { Total number } \\
\text { of insurers }\end{array}$ & $\begin{array}{c}\text { Number of } \\
\text { “non-life" } \\
\text { insurers }\end{array}$ & $\begin{array}{c}\text { Nominal } \\
\text { GDP, } \\
\text { billon \$ }\end{array}$ & $\begin{array}{c}\text { Assets of } \\
\text { insurers, } \\
\text { billon \$ }\end{array}$ & $\begin{array}{c}\text { Gross } \\
\text { Premiums, } \\
\text { billion \$ }\end{array}$ \\
\hline 2004 & 387 & 342 & 64.878 & 3.760 & 3.653 \\
\hline 2006 & 411 & 356 & 107.762 & 4.752 & 2.739 \\
\hline 2008 & 469 & 396 & 180.001 & 7.961 & 3.201 \\
\hline 2010 & 456 & 389 & 136.007 & 5.700 & 2.899 \\
\hline 2012 & 415 & 355 & 175.785 & 7.035 & 2.689 \\
\hline 2014 & 382 & 325 & 133.502 & 5.911 & 1.705 \\
\hline 2016 & 310 & 271 & 93.357 & 2.195 & 1.331 \\
\hline 2017 & 296 & 261 & 112.153 & 2.156 & 1.633 \\
\hline 2018 & 285 & 254 & 125.830 & 2.334 & 1.805 \\
\hline 2019 & 249 & 223 & - & 2.450 & - \\
\hline
\end{tabular}

Source: Annual reports of (the National Commission for State Regulation of Financial Services Markets) and official exchange rates (The National Bank of Ukraine). 


\section{Minimal Ukrainian Salary}

In the following section, we compare the salaries of low-income people using minimum wage as a key parameter. The value of the minimal Ukrainian salary (MUS) is very important due to the fact that it is codified by Ukrainian labour legislation and regulation laws (The budget Code of Ukraine, 2010). In Ukraine, this amount is defined as monthly value per person (unlike standard practice in many countries, where salary is calculated per calendar year).

The Ukrainian unit currency is the hryvnia, with the code "UAH" (The National Bank of Ukraine). During the 2011-2013 period, the exchange rate was within a range of values of $7.9 \mathrm{UAH}=\$ 1$ (in 2011) and 8.1UAH= $\$ 1$ (in 2013). For this study, we use a weighted average exchange rate for turning the Ukrainian unit currency into US dollars at the level 8UAH= $\$ 1$.

The minimal salary in 2011-2013 was equal to nearly 1000UAH per month (Law on the state budget of Ukraine, 2011; Law on the state budget of Ukraine, 2013). Turning the Ukrainian unit currency into US dollars or Euros for international comparison purposes yields that 1000UAH was approximately equivalent to $\$ 125$ or 90 euro per month at that time. It yields $\$ 4.2$ or 3 euro per day. On the other hand, the minimal salary in 2018 was equal to $3720 \mathrm{UAH}$ per month (Law on the state budget of Ukraine, 2018). Again, it yields nearly $\$ 135$ or 124 euro per month, equivalent to $\$ 4.5$ or 4 euro per day. These values correspond to the value determined by the United Nations for the Sustainable Development Goals (United Nations). In other words, the situation in Ukraine for the poor is still not good and not too much has changed.

To get the whole picture, we give the average price of one life insurance policy in 2011, which was found by looking at all insurance premiums in the life sector paid by a physical body (1183 million UAH) and the corresponding number of life insurance policies in 2011 (949 thousand contracts). Simple algebra gives the price 1247UAH per one life contract, which is larger than the official MUS value (1000UAH) at that time. It is self-evident that such a price cannot be afforded by poor people.
At present, there is no supplier for low intervals of insurance costs, from 0 to $\$ 12.5$ per month. In other words, the sector of minimally priced insurance, which could satisfy the demands of the poor, remained unmeasured. Our investigation was conducted to establish the 'demand' for and within low price interval insurance.

\section{Probable clients for microinsurance in Ukraine}

Let us now answer the question of who the most probable clients of microinsurance in Ukraine would be. For this exploration, we use the approach proposed by (Shirinyan, 2012a), with our modifications. Let us take a slightly abstract angle and imagine the traditional Ukrainian bowl, which should be filled up with borscht (in Slavic countries, a dense soup based on beetroot, potatoes, and cabbage) at the best. The occupancy degree for such a bowl may be a qualitative criterion of the prosperity level or, in other words, income. We conditionally divided the whole population of Ukraine into three categories: poor, relatively poor (not wealthy), and not poor (wealthy, rich, and oligarchs), which is shown in fig. 1 as the 'stratification bowl.' We divided the 'stratification bowl' by two conditional parts: formal and informal (shadow). The left (bottom-up) axis represents the income. On the right, the population distribution in Ukraine by the number of people in each category is shown by the line segment on the 'part of population' axis.

This 'stratification bowl' (Fig. 1) shows that there are much more poor (sector at the bottom), and relatively poor (sector at the middle), people than people who are not poor (at the upper strata) in Ukraine. Then the formally impoverished and officially poor population are the most liable for microinsurance service with government support, as well as for voluntary microinsurance in the absence of government schemes. 


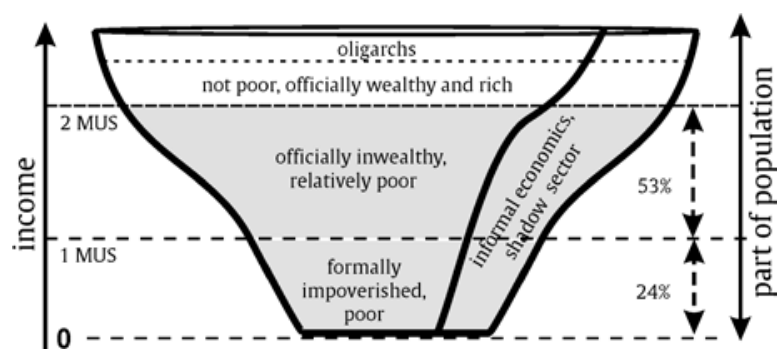

Figure 1 'Stratification bowl' interrelated with income and part of population in official and shadowed sectors. The left (bottomup) axis represents the income whereas the right axis shows in percentage the distribution of population from the number of people in each category. Microinsurance can include two ranks of society: poor ( $24 \%$ of population with $1 \mathrm{MUS}$ income at the most), and relatively poor (53\% of population with more than 1MUS and less than 2MUS income).

Source: Developed by authors.

In the considered years of 2011-2013, estimates of the percentage of the population falling below the poverty line give a value of 24\% (Central Intelligence Agency, 2014; State Statistics Service of Ukraine, 2013). According to the State Statistics Service of Ukraine (2014), during the $2010-2014$ period, nearly $24 \%$ of that population had an average income less than 1MUS (90 euro per month and per person), and nearly $77 \%$ of that population had an income less than 2MUSs (180 euro per month and per person). Other data based on the "subjective poverty incidence" (assessed through respondents' self-identification as representatives of certain population groups based on their level of well-being) for the years 2011-2013 identify the poverty level at 66\%. From this, we can determine who in Ukraine may be considered poor and relatively poor: the poor have an income not more than 1MUS and the relatively poor have an income of more than 1MUS, but not more than 2MUSs.

The existing distribution of the adult population of Ukraine on the measure age is nonmonotonic, with a maximum within the ages of 30-50 years (Central Intelligence Agency, 2014). On the other hand, the distribution of the adult population of Ukraine on the level of poverty has maximum values for people aged 20 to 40 years (lowest poverty rate is for $55-60$ years old people). This means that the main potential customer of microinsurance services will be mostly poor people aged $25-50$ years.

\section{RESEARCH METHODOLOGY \\ Contingent valuation approach}

The contingent valuation method uses direct information from people, gathered in a survey. Typically, the survey asks how much money people would be willing to pay for services (Venkatachalam, 2004). It is based on suggestions of hypothetical scenarios. Because the approach creates a hypothetical marketplace in which no actual transactions are made, contingent valuation is suitable for commodities that are not exchanged in regular markets.

The contingent valuation approach uses four sequential main steps in realising the survey and its corresponding analysis:

i) choice of services and the relevant population;

ii) decisions about the survey itself (including whether it will be conducted in person or by phone, who will be surveyed, and other related questions);

iii) survey design;

iv) implementation of the survey (Diamond and Hausman, 1994).

The following various survey methods are possible:

i) in-person interviews, which are the highest-quality, but are very expensive;

ii) telephone surveys, which are less expensive, but do not use visual aids;

iii) mail surveys, which are cheap, but become difficult answers depend on previous questions; and

iv) samples by intercepting passers-by at, for instance, shopping malls.

The hypothetical scenario in our work considers the situation of the introduction of microinsurance provided to low-income people by insurance services. Concerning possible approaches, since microinsurance in Ukraine 
does not exist, other traditional methods will be less effective.

As the first step, one should determine exactly what services are being valued, and who comprises the relevant population. The relevant population in our case must be citizens of the Ukraine, due to the 'stratification bowl' in fig. 1 discussed in the previous section and be either poor (income is no more than 1MUS) or relatively poor (income is more than 1 MUS but less than 2MUS). In our investigation, the people from 18 to 65, whose income is less than 2MUSs, are to be understood as the poor population. Furthermore, we selected people who do not possess the possibility of saving money in case of complications that may occur, and who save no more than a third of MUS (up to 300UAH per month) for analysis. We also distinguished those for whom the loss of personal income was critical for their family budget, because poorer families have limited sources of income. People for whom we lack necessary data, who are under state social protection, or who do not have their own personal income - for instance housewives, disabled people, unemployed or temporarily out of work people (pregnant or on maternity leave) and students - were separated from the statistical analysis. After that procedure, 520 citizens remained out of $3000 \quad(17.3 \%$ of respondents), among them: administrative employees (158), labourers (238), pensioners 65 years and younger (108), and teachers (16).

We considered the following list of possible insurance services: personal accidents, property, death, health, credit, small-scale business, goods, damage, crop / harvest, unemployment, and disability. In order to determine most suitable insurance services for low-income people, we prepared the corresponding question: "What would you like to be insured first of all?" and during the survey offered each interviewee to choose an answer among the possible variants. We also offered respondents to give their own variant.

The second step is to make decisions about the survey. We made the survey an in-person interview about insurance because explaining the required information to respondents in person was easier, and people were more likely to complete a long survey. In our study, we used face-to-face interviews (the interviewers were the authors).

The third step is the survey design. The set of questions is designed to measure the importance of insurance for citizens, their relationship with national insurance providers, and the possibilities of introducing microinsurance. (Because of restrictions on paper size we do not present the questionnaire here.)

The fourth step is the actual implementation of the survey. The polling was conducted during the years 2011-2013 in the town of Cherkasy and the Cherkasy region (geographically, part of central Ukraine), which covered about 3000 people ages 18 to 65 of different social status and income: teachers, physicians, enterprisers, employees, toilers, pensioners, hirelings, etc. The test site was mainly the streets of the town of Cherkasy, and the survey was done by random sampling. We offered each respondent to check all answers that apply, speak their answers to the interviewers, or give their own variant. As such, there might be multiple answers on each question.

A detailed discussion of the whole survey is not the topic of this article, but some results are presented for understanding respondents' preferences. The survey (3000 people) confirmed that: $70 \%$ of interviewees have no specific knowledge about insurance; $65 \%$ do not want to be insured at all; $68 \%$ do not trust to Ukrainian insurers; $52 \%$ would like to be insured by a governmental insurance company; and 36\% are ready to choose a foreign insurer instead of Ukrainian company. Thus, the results show that the population's level of insurance culture is very low, as illustrated by the result that people want to be insured by governmental insurer when, since 1993, there has been no governmental insurer in Ukraine.

Next, we zoom in on the poor population poll. In the worked-out questionnaires, we asked maximally simply formulated questions, which would be understandable even for those who are not aware of insurance. Among the possible answer options, we offered 11 types of risks for which microinsurance would be offered. Each respondent had been invited to define their own risks they would like to be insured. The results demonstrate that respondents would like to be 
insured for the following: i) health (40\% of respondents), ii) death (21\%), iii) property (16\%), iv) accidents (12\%), v) loan (6\%), and vi) harvest (4\%). Thus, the main risk is directly related to health insurance, which is likely because in Ukraine, obligatory health coverage is not provided by the government to citizens.

The one of the key questions was "What sum of money would you be willing to pay for insurance annually?" The other key question was question "How much money would you like to get back according to your payment in case of an insurance event arising?" The answers to these two key questions helped us to assess microinsurance services for low-income people based on different criteria, which are discussed further in the next section.

The final fifth step of the methodology is to report and analyze the results. The data must be entered and analysed using statistical techniques appropriate for the type of question.

\section{KEY FINDINGS AND DISCUSSION}

Empirical assessment of annual payment for microinsurance
Table 2 represents the answer to the first question "What sum of money would you be willing to pay for insurance annually?"

Criterion. We chose simple statistical criteria about satisfying conditions for people's desire to be insured. The price is suitable for people if it covers more than $50 \%$ of interviewees within the same income interval (same row in Table 2). We assumed that the interviewees who agreed on a certain price will also agree for lower prices. Then we can add respondents of the same income interval in order to find the potential scope of people wishing to pay less than some fixed price (annual insurance contract price).

We see that a microinsurance policy price of 10UAH (\$1.25) is the optimal price, covering more than $90 \%$ of poor interviewees. More detailed analysis shows that an insurance premium of 50UAH (or \$6.25) can satisfy most of the poor interviewees, except those who have the lowest income of 800-1000UAH (only 36.2\% of such interviewees agreed with that price). Thus, we acquire the first result of our inquiry: the most suitable price for more than half of Ukrainian low-income people fluctuates up to 30UAH, which can be considered to be the desired premium.

Table 2. Potential scope of poor population by microinsurance depending on income and the annual insurance contract price

\begin{tabular}{|c|c|c|c|c|c|c|}
\hline \multirow{3}{*}{$\begin{array}{l}\text { Monthly } \\
\text { income of a } \\
\text { person } \\
(\$)\end{array}$} & \multirow{3}{*}{$\begin{array}{l}\text { Monthly } \\
\text { income of a } \\
\text { person } \\
\text { (uah) }\end{array}$} & \multicolumn{5}{|c|}{$\begin{array}{l}\text { Microinsurance contract price (uah), which is } \\
\text { satisfying person }\end{array}$} \\
\hline & & 10 & 30 & 50 & 70 & 90 \\
\hline & & \multicolumn{5}{|c|}{ percent of interviewees, $\%$} \\
\hline $100-125$ & $800-1000$ & 97 & 54.4 & 36.2 & 30.5 & 27.6 \\
\hline $125-150$ & $1001-1200$ & 95 & 73.9 & 58.5 & 43.1 & 40.0 \\
\hline $150-175$ & $1201-1400$ & 98 & 76.3 & 66.6 & 61.9 & 59.4 \\
\hline $175-200$ & $1401-1600$ & 94 & 70.8 & 60.1 & 45.0 & 42.3 \\
\hline $200-225$ & $1601-1800$ & 96 & 78.1 & 61.0 & 53.7 & 43.9 \\
\hline $225-250$ & $1801-2000$ & 97 & 75.0 & 65.0 & 59.2 & 56.7 \\
\hline
\end{tabular}

Source: Own calculations based on the survey. The value in the table is the percent from total number of interviewees with certain income (row of the table), who agreed to pay such value. Bold numbers (yellow cells) correspond to the criterion of 50\%.

In the following, we use the notion of 'desired premium,' and also refer to this value as 'contract price' or the price $\operatorname{Pr}$ for usability, under the assumption that this value is the price for microinsurance services to be received in the contract. Looking at table 2 in more detail, we see the conventional demand relationship: the 
larger the contract price, the less the fraction of people who agreed on that price.

This absolute result $P r=30 \mathrm{UAH}$ can be reviewed in terms of MUSs to be unified:

$$
P r=3 \% \text { of MUS. }
$$

Then we can assume that the desired size of an annual microinsurance premium in Ukraine is about 3\% of MUS (MUS is not to be confused with the desired microinsurance contract price, which is annual value, whereas MUS is per month). A study by Dror found similar results for India: about two-thirds of the sample agreed to pay 1\%; about half the sample was willing to pay $1.35 \%$; and $30 \%$ was willing to pay about $2.0 \%$ of annual household income as a health insurance premium (Dror, Radermacher and Koren, 2007).

\section{Empirical assessment of annual microinsurance coverage}

Examining the insurance coverage value that may be suitable for the poor population in Ukraine, Table 3 represents the answer to the question "How much money would you like to get back according to your payment in case of an insurance event arising?»

Criterion. Those who agreed on some certain coverage value are assumed to also then agree on larger values. Then we can add respondents of the same income interval in order to find the potential scope of people wishing for more than some fixed coverage value. As a result, we have a distribution of the number of interviewees from desired coverage values and incomes.

Table 3. Potential scope of poor population by microinsurance depending on income and the annual insurance coverage value

\begin{tabular}{|c|c|c|c|c|c|c|c|c|c|c|}
\hline \multirow{3}{*}{$\begin{array}{l}\text { Monthly } \\
\text { income of a } \\
\text { person } \\
\text { (US \$) }\end{array}$} & \multirow{3}{*}{$\begin{array}{l}\text { Monthly } \\
\text { income of a } \\
\text { person } \\
\text { (uah) }\end{array}$} & \multicolumn{9}{|c|}{$\begin{array}{l}\text { Annual microinsurance coverage (thousand uah) per one } \\
\text { policy, which is satisfying poor people }\end{array}$} \\
\hline & & 1 & 2 & 3 & 4 & 5 & 10 & 20 & 30 & $>30$ \\
\hline & & \multicolumn{9}{|c|}{ percent of interviewees, \% } \\
\hline $100-125$ & $800-1000$ & 35.9 & 62.6 & 70.2 & 74.8 & 78.6 & 83.2 & 86.3 & 91.6 & 97.7 \\
\hline $125-150$ & $1001-1200$ & 13.6 & 45.5 & 60.6 & 66.7 & 75.8 & 86.4 & 89.4 & 95.5 & 98.5 \\
\hline $150-175$ & $1201-1400$ & 17.5 & 32.5 & 57.5 & 62.5 & 70.0 & 77.5 & 82.5 & 92.5 & 97.5 \\
\hline $175-200$ & $1401-1600$ & 14.0 & 43.9 & 59.8 & 64.5 & 74.8 & 79.4 & 82.3 & 89.7 & 97.0 \\
\hline $200-225$ & $1601-1800$ & 12.2 & 43.9 & 56.1 & 61.0 & 68.3 & 78.1 & 85.4 & 92.7 & 100 \\
\hline $225-250$ & $1801-2000$ & 20.5 & 41.8 & 54.9 & 59.0 & 68.0 & 77.9 & 82.8 & 91.8 & 98.4 \\
\hline
\end{tabular}

Source: Own calculations based on the survey. The value in the table is the percent from total number of interviewees with certain income (row of the table), who agreed for such value. Bold numbers (yellow cells) correspond to the criterion of $50 \%$.

We again use the statistical criterion for the satisfying condition for poor people if it covers more than $50 \%$ of interviewees in the same income interval (same row in table 3 ). We see that microinsurance coverage of 1000UAH is not suitable for most poor citizens, while coverage of 2000UAH is suitable only for those people who have an annual income of 800-1000UAH (nearly $62.6 \%$ of such interviewees can agree with such coverage). Thus, we arrive at the second result of our inquiry: the most suitable coverage for more than half the population fluctuates from 3000UAH, which may be considered as the 'desired coverage.'
In the following, instead of 'desired coverage,' we also use the notion 'desired insurance compensation' and 'insured sum,' $S$, under the assumption that this value may be the amount of money that an microinsurance company is obligated to cover in the event of a covered loss.

The absolute result $S=3000 \mathrm{UAH}$ can be reviewed in terms of the MUSs to be unified:

$$
S=3 \text { MUSS }
$$

Then we can assume that the desired size of annual microinsurance coverage in Ukraine is about 3MUSs. 
Since only $36 \%$ of most poor people with an income of 800-1000UAH agreed for 1000UAH, showing indirectly that they are displeased by the MUS value in Ukraine.

Another interesting result is that microinsurance is rational for poor people: they benefit more from insurance of a given monetary sum, preferring a certain gain to an uncertain gain of the equivalent value.

\section{The assessment of desired tariff on microinsurance services}

Can microinsurance be a business proposition? To answer this question, we need to one start looking at the problem in terms of potential commercial microinsurance providers.

In practice, insurance companies determine the insurance service price by finding the tariff $(T)$, which is part of insurance coverage. To find the microinsurance tariff, we can use the annual microinsurance coverage, $S$, as the reference value. Then it is possible to find the correlation between the desired premium, $P r$, and desired microinsurance coverage.

The simplest way to estimate the microinsurance tariff is to determine the ratio between the desired contract price Pr and desired coverage $S$ :

$$
T=\operatorname{Pr} \mid S \cdot 100 \%=30 \mathrm{UAH} / 3000 \mathrm{UAH} \cdot 100 \%=1 \% \text {. }
$$

Hence, the tariff is nearly $1 \%$ of microinsurance coverage and may be suitable for more than a half of the poor population. This value can be called a 'desired microinsurance tariff.'

If we intensify the last criterion (say, instead of $50 \%$, we can use $75 \%$ of agreed poor population) then the enabling cost of the microinsurance policy will be lower and desired coverage will be higher. For this $75 \%$ criterion, 'desired tariff equals nearly $0.4 \%$ of the insurance sum ( $P r=20 \mathrm{UAH}$ and $S=5000 \mathrm{UAH})$. That is why the choice of the criterion is important and has high impact on the tariff.

There is also another way to estimate the average desired tariff. Answers from interviewees offered the possibility of finding a ratio of values for each respondent ratio desired premium (contract price) to desired compensation (sum insured under agreement).
This ratio is actually also an individual desired insurance tariff $T_{i}$, that is the microinsurance service price suitable for a certain person (subindex $i$ is the number of the respondent).

We could find such an individual tariff from the responses of 450 out of 520 completed survey forms (450 replies were valid) where they mentioned an average rate (arithmetic mean value) of about $T_{\text {avg }}=3.8 \%$ :

$$
T_{\text {avg }}=100 \%\left(\Sigma T_{i}\right) / 450=3.8 \% \text {. }
$$

Note that such an average offers the value of the desired tariff with respect to the agreed insured sum and says nothing about statistical distribution of tariffs. For detailed analysis, we must consider tariff distribution, which will be presented elsewhere.

For comparison, traditional voluntary insurance in Ukraine deals with annual tariffs that vary, as a rule, from $1 \%$ to $15 \%$ of the insurance sum: on average, 1-5\% for casualty insurance, $5-15 \%$ for life insurance, $2-14 \%$ for health insurance, $4-10 \%$ for motor insurance, and $5-16 \%$ for agricultural insurance (The National Commission for State Regulation of Financial Services Markets, 2013).

\section{CONCLUSIONS}

We tested the hypothesis using questionnaires and statistical analysis of the needy population in Ukraine about the correlation between preferred insurance premiums and desirable insurance reimbursement. The inquiry for the years 20112013 shows that poor people benefit more from insurance of a given monetary sum and prefer a certain gain to an uncertain gain of the equivalent value. The desired size of the annual microinsurance premium fluctuates from $\operatorname{10UAH}(\$ 1.25 \$)$ to $30 \mathrm{UAH}(\$ 3.75)$, and the desired size of insurance indemnity from $3000 \mathrm{UAH}(375 \$)$. In relative units, the desired amount for annual microinsurance premiums in Ukraine is about $3 \%$ of MUS, and the desired amount of annual microinsurance coverage in Ukraine is not less than 3 MUSs.

The poorest people prefer a microinsurance tariff at a rate of $1 \%$ of desired coverage, whereas the average rate of the desired tariff according to the survey makes about $T_{\text {arg }}=3.8 \%$. 
In our opinion, these results concerning the needy population of Ukraine could be expanded to other Eastern European countries with postcommunist transition economies and similar economic problems.

\section{ACKNOWLEDGMENT}

The research is supported by the Ministry of Education and Science of Ukraine (certification 0117U001246, order №198 dated 10.02.2017).

\section{REFERENCES}

Berliner, B. (1982). Limits of Insurability of Risks. Englewood Cliffs, NJ: Prentice-Hall.

Biener, C. and Eling, M. (2012). Insurability in Microinsurance Markets: An Analysis of Problems and Potential Solutions, The Geneva Papers 37, pp. 77-107.

Binnendijk, E., Dror, D., Gerelle, E. and Koren, R. (2013). Estimating willingness-to-pay for health insurance among rural poor in India, by reference to Engel's law, Social Science and Medicine 76(1), pp. 67-73.

Central Intelligence Agency (2014). The World Factbook. Europe: Ukraine. Retrieved March 8, 2014 from: https://www.cia.gov/library/publications/th e-world-factbook/geos/up.html.

CGAP Working group on Microinsurance, (2008). Providing insurance of real value to the poor, Microinsurance in Focus, 12, pp. 12.

Churchill, C. (ed.) (2006). Protecting the poor - a microinsurance compendium. International Labor organization in association with Munich Re Foundation. Munchen: Germany, Geneva: Switzerland.

Churchill, C. (2007). Insuring the Low-Income Market: Challenges and Solutions for Commercial Insurers, The Geneva Papers on Risk and Insurance-Issues and Practice 32(3), pp. 401-412.

Churchill, C., \& Matul, M. (ed.) (2012). Protecting the poor - a microinsurance compendium. Volume II, International Labor organization in association with Munich Re Foundation. Munchen: Germany, Geneva: Switzerland.
Diamond, P. A., Hausman, J. A. (1994). Contingent valuation: is some number better than no number? Journal of Economic Perspectives 8 (4), pp. 45-64.

Dror, D. M., Jacquier, C. (1999). Micro-insurance: extending health insurance to the excluded, International Social Security Review 52 , pp. 71-97.

Dror, D. M., Radermacher, R., Koren, R. (2007). Willingness to pay for health insurance among rural and poor persons: Field evidence from seven micro health insurance units in India, Health Policy 82(1), pp. 1227.

Grebenshchikov E. S. (2007). Microinsurance is not quite ordinary insurance and not only for the poor, Finance 10, pp. 47-51. (Original work written in Russian)

Holst, J. (2005). Health Microinsurance: A Comparison of Four Publicly-run Schemes Latin America, CGAP Working group on Microinsurance: good and bad practices, Case Study 18, p. 76.

International Labour organization (2015). The ILO's impact insurance facility. Annual Report 2014. International Labour Office: Geneva.

Law on the state budget of Ukraine for 2011 (2010, December 23). № 2857-VI. Webportal of Institution "Profi Wins". Retrieved September 05, 2016 from: http://www.profiwins.com.ua/uk/legislation /laws/1435.html.

Law on the state budget of Ukraine for 2013 (2012, December 6). Web-portal of Ukrainian Government. Retrieved September 14, 2018 from: https://zakon.rada.gov.ua/laws/show/551517?lang=en.

Llanto, G. M., Geron, M. P., Almario, J. (2007). Developing Principles for the Regulation of Microinsurance (Philippine Case Study). Philippine Institute for Development Studies: discussion paper series 26, p. 80.

Matul, M., \& Durmanova, E., Tounitsky, V. (2006). Market for Microinsurance in Ukraine. Low-Income Households Needs and Market Development Projections. 
Microfinance Centre for CEE and the NIS: Warsaw.

McCord, M. J. (2007). Supplying Health Microinsurance: Lessons from East Africa, International Journal of Public Administration 30, pp. 737-764.

McCord, M. J., Ramm G., McGuinness, E. (2006). Microinsurance: demand and market prospects - Indonesia. UN's global development network, Public-private partnership. Allianz AG: Deutsche Gesellschaft fur Technische Zusammenarbeit. Retrieved November 22, 2018 from:

https://www.findevgateway.org/library/mic roinsurance-demand-market-prospectsindonesia.

Microinsurance Network. Retrieved January 5, 2019 from: http://www.microinsurancenetwork.org/.

Munich Re Foundation. From knowledge to action. Retrieved October 5, 2018 from: http://www.munichrefoundation.org/home.html.

Opportunity International. Retrieved August 28, 2018 from: https://opportunity.org/aboutus/.

Ramachandran, V. (ed.). (2012). Encyclopedia of Human Behavior. Elsevier/Academic Press: London.

Shirinyan, L. V. (2010). Microinsurance - New Direction of Insurance Activity Development in Ukraine, Regional Economy 2, pp. 141150. (Original work written in Ukrainian)

Shirinyan, L. V. (2012a). Targeted microinsurance, Actual Problems of Economics 8(134), pp. 272-279. (Original work written in Ukrainian)

Shirinyan, L., \& Shirinyan, A. (2012). Microinsurance in Ukraine: to be or not to be: monograph, Publishing house: Chabanenko Y. A., Cherkasy. (Original book written in Ukrainian with translated title, contents)

State Statistics Service of Ukraine (2014). Distribution of the population by average per capita equivalent total income. Retrieved May 22, 2015 from: http://ukrstat.org/en/operativ/operativ2007 /gdvdg_rik/dvdg_e/roz2006_e.htm.

State Statistics Service of Ukraine (2013, November 22). Poverty Measurement in Ukraine: Criteria, Challenges and Prospects. United nations: Economic Commission for Europe Conference of European statisticians. Seminar "The way forward in poverty measurement" 2-4 December 2013, Geneva, Switzerland. Working paper 12. Retrieved May 22, 2018 from: http://www.unece.org/fileadmin/DAM/stats /documents/ece/ces/ge.15/2013/WP_12_Ukr aine_D_En.pdf.

The Budget Code of Ukraine (2010). Vidomosti Verkhovnoyi Rady Ukrayiny 50-51, p.572. Retrieved October 12, 2018 from: http://gogov.org.ua/wpcontent/uploads/2016/05/THE-BUDGETCODE-OF-UKRAINE.pdf.

The National Bank of Ukraine - Official website. Exchange rate of Hryvnia against foreign currencies. Retrieved October 9, 2018 from:

http://www.bank.gov.ua/control/en/curmet al/detail/currency?period=daily.

The National Commission for State Regulation of Financial Services Markets. - Official website. Retrieved October 22, 2018 from: https://www.nfp.gov.ua/.

The National Commission for State Regulation of Financial Services Markets (2013). Order 4370 dated 28.11.2013 "On Approval of the Methodology for Determining the Price of the Insurance Tariff". - Web-portal of Ukrainian Government. Retrieved June 20, 2014 from: http://zakon4.rada.gov.ua/laws/show/z2091 $-13$.

The World Bank Group (2018). Poverty and Shared Prosperity 2018: Piecing Together the Poverty Puzzle. World Bank Publications, Washington. Retrieved November 27, 2018 from: http://www.worldbank.org/en/publication/ poverty-and-shared-prosperity.

United Nations. The Sustainable Development Goals. Goal 1: End poverty in all its forms everywhere. Retrieved November 22, 2018 from: 
https://www.un.org/sustainabledevelopmen t/sustainable-development-goals/

Venkatachalam, L. (2004). The contingent valuation method: a review. Environmental Impact Assessment Review 24, pp. 89-124.

Wiedmaier-Pfister, M., \& Klein, B., Denker, H., Wagner, J. (2009). Security at little cost microinsurance in Financial Systems Development. BMZ Position Paper: Microinsurance - a field of activity for German development policy. Strategies 179. Federal Ministry for Economic Cooperation and Development: Bonn.

Yao, Y. (2013). Development and Sustainability of Emerging Health Insurance Markets: Evidence from Microinsurance in Pakistan. The Geneva Papers 38, pp. 160-180.

\section{ABOUT THE AUTHORS}

Lada Shirinyan, email: ladashirinyan@ukr.net

Dr. Lada Shirinyan is head of the Department of Finance at the National University of Food Technologies, Kyiv, Ukraine. She studied finance and credit at Sankt-Petersburg State University of Economics, Russia. Dr. Sirinyan received a Ph.D. in Finance and Credit, Candidate of Sciences, and Doctor habil of Economic Sciences. Her research areas cover finance and insurance, the competition of banks in Eastern Europe, decision economics and psychology, risk management, social economics, insurance of poor population, the competitiveness of insurance and financial companies, markets of financial services in Post-Soviet and European countries.

Dr. Aram Shirinyan is currently at the position of Leading Staff Scientist at the Research Laboratory of National University of Food Technologies, Kyiv, Ukraine. He has a Ph D in Physics and Mathematics and habilitated the thesis on Doctor of Sciences in 2012. His research areas cover competitiveness of banking services market, finance and insurance, modelling of the behavioral economics and processes in nature, microinsurance, financial markets, competitiveness of insurance undertakings in Eastern European countries. 